\title{
About Chediak-Higashi, Hemoglobin Lansing, and Hemoglobin Jabalpur
}

\section{Chediak-Higashi, Hemoglobin Lansing ve Hemoglobin Jabalpur Hakkinda}

Şinasi Özsoylu

Retired Professor of Pediatrics, Hematology, and Hepatology, Honorary Fellow of American Academy of Pediatrics, Honorary Member of American Pediatric Society

To the Editor,

I would like to express my concerns about some of the published letters in a recent issue of this journal.

About "A Rare Cause of Recurrent Oral Lesions: Chediak-Higashi Syndrome" by Karabel et al. [1], I feel that unbelievably low neutrophil counts (157/L ?) and/or coinciding presence of another hereditary disorder such as acatalasemia [2] should also be looked for as a cause of oral lesions.

It was nice seeing the addition of "Hemoglobin Lansing (Alpha) [HBA2 CD87 (HIS>GLU) $(\mathrm{C}>\mathrm{A})$ ] in a Turkish Individual Resulting from Another Nucleotide Substitution" to the hemoglobinopathy library in our country by Akar et al. [3]. More interestingly, these studies were carried out in a hematologically almost normal female (hemoglobin: 13.1 g/dL; MCV: $95 \mathrm{fL}$ ) for premarital counseling! The authors should give an explanation for this counseling in a female in the absence of family history and the presence of normal hemoglobin level.
Dr. Çolak and her colleagues [4] also added another hemoglobin to the Turkish hemoglobinopathy library with their letter entitled "First Observation of Hemoglobin Jabalpur [Beta3 (NA3) Leu >Pro] in the Turkish Population". Since findings of reticulocyte count, plasma hemoglobin level, peripheral smear, etc. were not given, the cause of mild anemia in the proband and his mother should be studied.

\section{Conflict of Interest Statement}

The author of this paper have no conflicts of interest, including specific financial interests, relationships, and/ or affiliations relevant to the subject matter or materials included.

Key Words: Chediak-Higashi, Hemoglobin Lansing, Hemoglobin Jabalpur

Anahtar Sözcükler: Chediak-Higashi, Hemoglobin Lansing, Hemoglobin Jabalpur

Address for Correspondence: Şinasi ÖZSOYLU, M.D.,

Retired Professor of Pediatrics, Hematology, and Hepatology, Honorary Fellow of American Academy of Pediatrics, Honorary

Member of American Pediatric Society E-mail: sinasiozsoylu@hotmail.com

Received/Geliş tarihi : October 02, 2014

Accepted/Kabul tarihi : October 13, 2014 


\section{References}

1. Karabel M, Kelekçi S, Sen V, Karabel D, Aliosmanoglu C, Söker M. A rare cause of recurrent oral lesions: ChediakHigashi syndrome. Turk J Hematol 2014;31:313-314.

2. Takahara S, Hamilton HB, Neel JV, Kobara TY, Ogura Y, Nishimura ET. Hypocatalasemia: a new genetic carrier state. J Clin Invest 1960;39:610-619.

3. Akar N, Torun D, Öztürk A. Hemoglobin Lansing (alpha) [HBA2 CD87 (HIS>GLU) (C>A)] in a Turkish individual resulting from another nucleotide substitution. Turk J Hematol 2014;31:317-318.

4. Colak A, Toprak B, Yararbas K, Akyol F, Ceylan C. First observation of hemoglobin Jabalpur [beta 3 (NA3) Lac>Pro] in the Turkish population. Turk J Hematol 2014;31:319320.

\section{Reply}

In Turkey, several issues including a mass screening program for the prevention of hemoglobinopathies have been taken since 2000. A hemoglobinopathy control (prevention) program was begun in 33 provinces in 2003 according to the regulations released by the Turkish Ministry of Health [1].

Our patient was subjected to hemoglobin electrophoresis prior to marriage. When abnormal hemoglobin was detected, she was sent for genetic counseling to our center.

\section{Nejat Akar, M.D., Prof. \\ TOBB-ETU Hospital, Clinic of Pediatrics, Ankara,} Turkey

\section{Reference}

1. Canatan D, Aydinok Y, Kılınç Y, Karakaş Z, Şaşmaz İ, Apak H, Sarper N. National Thalassemia Prevention Campaign: The Talotır Project. Turk J Hematol 2013;30:91-92. 